\title{
Transversal Connections: The Cervantes Quatercentenary in Spain and its Comparison with "Shakespeare Lives"
}

\begin{abstract}
Taking as its cue the 2016 quatercentenaries of the deaths of both Shakespeare and Cervantes, the essay offers some insights into the "transversal connections" between both events as celebrated in Spain and the UK. The questions it raises and attempts to resolve are fourfold: (1) What are the reasons and also the benefits of yoking together two such apparently disparate authors, whose strongest link is, arguably, the fact they both passed away in 1616? (2) What work is being done to restore these writers to life, especially in schools where, for a variety of reasons, literature has lost its core-curricular status, and in general society where the classics seem to have less and less import? (3) What might Shakespeare or Cervantes be said to stand for in their respective cultures, both in terms of the genres they wrote in (it is often forgotten, for instance, that Cervantes was also a poet and a dramatist) and the extra-literary values they are said to transmit? (4) What is the role of the State in the safeguarding and promotion of the nation's cultural heritage?
\end{abstract}

Keywords: Quatercentaries, Shakespeare, Cervantes, criticism, education, values, cultural industry.

Transversal connections are still waiting to be explored between the burgeoning Shakespeare cult of commemoration and the cult of European writers including Dante, Racine, Voltaire, Molière, Calderón, Cervantes, Goethe, and Schiller, who were all appropriated by the secular cult of hero-as-poet worship in the nineteenth century, so well envisioned by Thomas Carlyle. (Hoenselaars and Calvo 8)

The quatercentenaries of the deaths of both Shakespeare and Cervantes in 2016 provide plenty of evidence of such Carlylesque outpourings. The nearcoincidence of their deaths lent symbolic weight to their now widely

* University of Murcia, Spain.

${ }^{1}$ I am indebted to the Spanish Ministry of Economy and Competitiveness and project FFI-53587-P "The reception of Shakespeare's Work in Spanish and European Culture" for funding the research for this article. 
acknowledged status as twin peaks of a putative Western "canon" of great literature and, Pace Bloom et al., even of Western civilization as a whole. But it is important to remember that that status did not grow of its own accord, that it is something that has had to be worked on, and even fought for, over the last four centuries. Equally true is the fact that, once established, the authors' canonicity has had to be continually reaffirmed-if necessary, by political decree. The essay offers some insights into this process by considering the impact of Cervantes's death in Spain in 2016 and by comparing it to the British response to Shakespeare's. The questions it raises and attempts to resolve are fourfold: (1) What are the reasons and also the benefits of yoking together two such apparently disparate authors, whose strongest link is, arguably, the fact they both passed away in 1616? (2) What work is being done to restore these writers to life, especially in schools where, for a variety of reasons, literature has lost its core-curricular status, and in general society where the classics seem to have less and less import? (3) What might Shakespeare or Cervantes be said to stand for in their respective cultures, both in terms of the genres they wrote in (it is often forgotten, for instance, that Cervantes was also a poet and a dramatist) and the extra-literary values they are said to transmit? (4) What is the role of the State in the maintenance and perpetuation of the nation's cultural heritage? (Here in Spain the assumption continues to be that that heritage is dependent on direct government intervention, something that potential private sponsors have used as an excuse not to commit to cultural projects such as the commemoration of an author's death.)

\section{A Holy Alliance}

Is it not strange that on this common date,

Two titans of their age, aye of all Time,

Together should renounce this mortal state,

And rise like gods, unsullied and sublime? (Service 99)

Robert William Service's poetic tribute to Shakespeare and Cervantes is symptomatic of the way their joint deaths have been commemorated in Western culture. $^{2}$ The "strange" coincidence of the common date must mean something; but what? What bonds them as the "transcendant team" the poet imagines them to be in heaven, save for the wishful fantasy that there may after all be some reason they should pass away in the same year, if not quite on the same day?

${ }^{2}$ See Gregor ("Collaborative Encounters") for an attempt to unpick this poem and two recent Spanish fictionalizations: José Carlos Somoza's play Miguel Will (1999) and Inés París's film Miguel y William (2007). 
In Spain the pairing of Cervantes and Shakespeare in the kind of holy alliance Service imagines dates back to at least the decade of the 1830s, as traditional comparisons with the prolific playwrights Lope de Vega and Calderón de la Barca gave way to equally hazy valuations of the relative greatnesses of the man from Stratford and the "manco de Lepanto" (Pujante, "Shakespeare or/and..."). It was in this more mystic vein, for example, that the poet and playwright José Somoza (691) penned a dialogue between the pair where Cervantes acknowledges how both had overcome the adversities of humble background and physical impairment (sic) to attain "immortality on the wings of our genius". And though in an earlier essay Somoza had more promisingly alluded to the comic potentiality in both author's work to set the behaviour of "men of honour" against the carnivalesque antics of clowns (Pujante and Campillo 87), he falls short of outlining a common aesthetic. Instead, he confines himself to the observation that their different life-styles (Cervantes the soldierly man of action, Shakespeare the "static" stay-at-home actor) somehow actuated different artistic motivations and so choice of genre: narrative for Cervantes and drama for Shakespeare.

It is chiefly at this spiritual, artistically non-specific level that Cervantes and Shakespeare were twinned in the tercentenary celebrations in Britain and indeed much of the British empire (Kahn). In Spain, whose strict policy of neutrality in the Great War meant that any references to Cervantes' literary rival were carefully scrutinized and even muted (Calvo), Shakespeare was acknowledged chiefly as the author of light-hearted conservative comedies like The Taming of the Shrew (Gregor, Shakespeare 2010). True, at a purely symbolic level he was the man who had invented "Hamletism", the disease of paralysis and inaction which, as Salvador de Madariaga would powerfully argue, explains Spain's "secret desire for action and ... secret incapacity to do anything" (Pujante and Campillo 422). Aesthetically, however, he was not considered in the same league as Cervantes. After the war, once Spain had clarified its position vis-à-vis the former combatants, the comparisons between Shakespeare and Cervantes stepped up apace. But they continued to be blighted by a lack of critical rigour and failure to shed any light on the complex relations between them in terms of sources, resources and possible artistic intent. In the first editions of his complete works of Shakespeare, translator Luis Astrana Marin pointed to some common vectors between Shakespearean and Golden Age drama-only to abandon the idea of a possible link with Cervantes from the fourth edition. In 1944 Nicolás González Ruiz, who adapted a number of Shakespeare's works for the Spanish stage in the early years of the Franco dictatorship, discovered a common pattern in the lives of both authors: a humble upbringing and non-university education compensated for by their natural geniuses, the main difference between them being what González Ruiz sees as 
Shakespeare's “intuitiveness" versus Cervantes's greater "experience". In 1964, in an essay marking the tricentenary of Shakespeare's birth, Carlos Pujols adduces the Sonnets as evidence of the discrepancy between the kind of writer the poet wished to be and the kind of writer he actually was-a discrepancy mirrored in Cervantes' oscillations between more conventional work like Persiles and the groundbreaking Don Quixote. With the rise of English Studies in Spain in the latter part of the century, including the foundation of specialized associations and increased investment in relevant research (Monterrey), critics have revisited the relationship between the two writers. However, barring discussion of particular cases, such as the existence and Shakespeare's presumed authorship of Cardenio, the results of these enquiries have been far from conclusive. This was brought home at the twenty-seventh Conference of the Spanish and Portuguese Society for the English Renaissance held in 2016 in the Spanish city of Valladolid, an event which assembled some twenty-five scholars from both camps. Disappointingly, less than a quarter of the papers addressed possible comparisons (mainly shared sources) between them, the parallel sessions approach emphasizing the chasm between Hispanists and Anglicists in the comparative approach to both authors. As José Manuel González (11) laments in his 2006 volume Cervantes and Shakespeare, there remain "few publications and studies to have looked in any detail or depth at the comparative and contrastive features of their respective work or which defend and confirm the importance and impact of their literary legacy". By the time of the quatercentenary, the number had risen very little.

\section{Cervantes and Shakespeare "Live"}

But on to the quatercentenary itself. There is, as Nico Frijda has argued (111), a powerful socio-psychological compulsion to commemoration whose object is the obliteration of the distance, both spatial and temporal, separating us from the cherished "places" of memory. Such purely symbolic acts as the laying of wreaths, the penning of articles, production of TV shows, delivery of speeches, wearing of poppies, etc., serve to mitigate the loss of the object, keeping it alive in the individual and collective memory. However briefly, such acts "dissolve the discontinuities between now and the past, between one individual and others, between those who are there and who are not there any more" (Frijda 111). The kind of emotional investment Frijda addresses in his book may not run quite as deep in the case of the honouring of dead authors. But the compulsion to bring the commemorated object back to life still to a certain extent underpins the reverence. The description of Shakespeare in a British parliamentary debate marking the occasion of the quatercentenary as "our greatest living bard" 
is possibly less ingenuous than it sounds: ${ }^{3}$ made by the incumbent MP for Stratford-upon-Avon, the Kurdish-born Nadhim Zahawi, it expresses both a sense of Shakespeare's abiding influence on the present and, as hinted in the pronoun, his ability to speak for a communality of which the fervent pro-Brexit migrant is clearly proud to feel a part.

As if to assert the physical presence of both Shakespeare and Cervantes in their respective commemorations, the quatercentenaries were preceded by a hunt for the bones of both authors. Visits to the tombs of famous writers and the attendant desire to somehow "possess" the dead have, as Nicola Watson (29) has shown, been a feature of literary tourism from the nineteenth century. Ground-penetrating radar scans in the first case and DNA sampling in the second were simply the technological means to what essentially was the same necrophiliac end. Though frustrating in their findings-Shakespeare seems to be missing his skull, while Cervantes, if he exists at all, is scattered amongst a multitude of remains discovered in a common ossuary at a Madrid conventboth searches momentarily kept alive the illusion of a material object of celebration. ${ }^{4}$ Like the vapourized victims of $9 / 11$ or the First World War, such objects are not of course essential to the proper performance of the rituals of commemoration. In the case of writers whose work purportedly "outshines" both marble and the gilded monuments, neither the body (or absence thereof) nor the tomb in which it is (or is not) enshrined should be allowed to stand in the way of the worshipper's commemorative fervour. The discovery of a headless Shakespeare and a fragmentary and scattered Cervantes did not dampen the celebrations that followed, but it did bring to the fore the problematic nature of what have been known as the traditional "sites of memory", of which graves are an obvious instance. Amongst other things, the absence of the Shakespearean cranium and the dissemination of Cervantes seemed to bear out Astrid Erll and Ann Rigney's point (2) that “canonical 'memory sites' themselves have a history and, although they represent in many ways the terminus ad quem of repeated acts of remembrance, they only continue to operate as such as long as people continue to re-invest in them and use them as a point of reference". Without them, their occupants and what they allegedly stand for might simply cease to exist.

3 For an account of Zahawi's intervention and Hansard's tactful correction of it to "our greatest bard", see "Parliamentary Debates" (435).

4 The results of the Stratford investigation were presented in the Channel 4 documentary "Secret History: Shakespeare's Tomb" aired in Britain on 26 March 2016. A report of the Spanish search can be found on National Geographic's Spanish website under the title "Aquí yacen los huesos de Cervantes, o eso parece" ("Here lie the bones of Cervantes, or so it seems") (“Aquí yacen"). 
As well as possibly explaining the concern in the vicar of Holy Trinity's denial of the evidence on the Stratford tomb, ${ }^{5}$ the exposure of the historicity of Cervantes's remains added an urgency to the debates in Spain in the months leading up to the Cervantes event. In these, comparisons inevitably rose between the organization of the Cervantes fourth centenary and of "Shakespeare Lives". Thus, in a TV debate screened in April 2016 by the private channel Intereconomía, the presenter of the late-night programme "El gato al agua" (literally "cat in the water", an expression suggesting "winning the day" or "pulling it off") asked his guests whether they thought Spain was doing as much to honour the four hundredth anniversary of the death of Miguel de Cervantes as Britain was to commemorate Shakespeare. Given the nationalist, ultraconservative stance of the channel as a whole, the question was not an innocent one: the "debate" (which admittedly only lasted three minutes) was preceded by a prefatory video and narration where the words "controversy", "secrecy" and "fiasco" featured prominently. One regular panelist on the show stormed that the whole issue was a "question of state", that Spain (by which he meant the "soft" right ruling People's Party of Mariano Rajoy) was missing a golden opportunity to promote itself as both tourist destination (as if it really needed to) and home to the third most spoken language in the world. When it was politely pointed out to him that the government was already doing something, mainly by entrusting the celebrations to the Instituto Cervantes, an adjunct of the Ministry of Education, the irate panelist waved a dismissive hand as if to brush the whole quatercentenary aside.

The superficiality and brevity of the debate was perhaps as symptomatic of the medium in which it was held as it was of the seriousness of the topic being discussed. For a slightly more in-depth treatment non-specialists could also turn to national newspapers, in both their virtual and printed formats. But the conclusion there-that the government was not taking the Cervantes commemoration seriously enough, especially not when compared to the Shakespeare celebrations in Britain and the rest of the world-was largely similar. Nor did this necessarily depend on the ideological standpoint of the organ involved. In Vozpópuli, an online paper with a focus similar to that of Intereconomía, cultural editor Karina Sainz added statistical weight to the argument that Cervantes was getting a rough deal when it came to the attention being paid to two such national icons. "Over 140 countries throughout the world," she noted, "will be taking part in the commemoration of the fourth centenary of the death of Shakespeare" (Sainz Borgo), whereas for Cervantes, of 130 activities announced in October 2015 by the newly created National Committee for the Commemoration of the Fourth Centenary of the Death of

${ }^{5}$ His insistence that the search had failed to provide "sufficient evidence" to conclude the skull had been taken was extensively reported in both the British and the US press. 
Miguel de Cervantes (see below), only "around fifty" had been officially confirmed. As an example of what Cervantes biographer Andrés Trapiello saw as the authorities' disinterest and apathy regarding such a stellar event, Sainz cites the gaffe on the memorial plaque placed at the site of Cervantes's recently discovered bones: a quotation from the novella Los trabajos de Persiles $y$ Sigismunda (The Works of Persiles and Sigismunda), wrongly transcribed as "Los trabajos de Persiles y Segismunda". After an appreciative nod in the direction of the BBC and British Council's "Shakespeare Lives" programme, which included a series of events pitched specifically towards Spanish audiences, the author of the article echoes the concerns voiced by, among others, Darío Villanueva, head of the Real Academia de la Lengua, about Spain's rather lackadaisical approach to its own commemoration. To the National Committee's own "lack of foresight" should, Sainz hints, be added the apathy of private corporations which had so far failed to deliver.

The concerns of Vozpópuli were echoed at the other end of the ideological spectrum by the high-distribution centre-left daily El País. In an article published on the same day (28 January 2016), provocatively entitled "Let the English Keep Cervantes; They'll Treat Him Better" (Ruiz Mantilla), a number of high-profile writers and academics were invited to express their opinions on the forthcoming events. With a resumé of the "Shakespeare Lives" programme pointedly set on the right-hand side of the page, the opinions of the invited authors, Javier Marías, Arturo Pérez Reverte, Manuel Gutiérrez Aragón, Soledad Puértolas (all members of the official language academy, the Real Academia Española), Javier Cercas and Andrés Trapiello, feature on the left. Predictably, there is a unanimous condemnation of the authorities' lack of foresight but also of the lack of respect and even a certain "hostility" towards the classics which, for Marías, is "comparable to that which existed towards the world of culture in general under [the late dictator, Francisco] Franco". An example of what Cercas calls "the scorn for Cervantes felt by the elite of his own time", the hold-up in the commemoration proceedings is, for Trapiello, also symptomatic of the "indecency of our governors ... in a country which seems bent more on self-destruction than on self-construction". Without actually explaining the connection between this allusion to Catalan nationalism and the potential break-up of Spain and the fact that in a 2015 survey "only two in every ten Spaniards acknowledged that they'd ever read Don Quixote", ${ }^{6}$ Trapiello suggests that instead of digging up Cervantes's bones, "we should pay more

6 The survey he refers to, conducted by the Spanish Centro de Investigaciones Sociológicas (CIS), showed that only two in ten Spaniards had read the whole novel, while forty percent had not read any of it. Of those who had read all or some of it, mainly at school, half acknowledged that they did not know the protagonist's real name was Alonso Quijano. 
attention to his oeuvre, which is what's really alive"-just like Shakespeare's which, he claims, thanks to updated versions, has been miraculously restored to "life" in UK schools and theatres.

\section{The National Poets}

As well as the individual or communal need for proximity to the dead and the "coherence" (Frijda) that it seems to provide, the motives for such ceremonies can also be less "pure". In a volume on the symbolic aftermath of 9/11, David Simpson has argued that in the cultures of commemoration even such emotionally-charged events as the attack on the World Trade Centre

can become particularly sensitive occasions for assessing the balance of change and continuity within the culture at large. They often declare their adherence to time-honoured and even universally human rituals and needs, but nothing is more amenable to political and commercial manipulation than funerals, monuments, epitaphs, and obituaries. (1)

Across the post-catastrophe case studies examined in the volume lies the shadow of President George W. Bush's address to the nation in which what he interpreted as an attack on "our way of life, our very freedom" was the prelude to his "war on terror" speech in Congress where he thanked the House for the delivery of $\$ 40$ billion to "rebuild our communities and meet the needs of our military". While the military was instantly gratified, thus enabling the immediate start of the disastrous campaign in Afghanistan, the rebuilding work took much longer and proved far more expensive-as well as more polemical-than initially planned (Weikart 125). Even use of the Ground Zero memorial and museum for the annual commemoration of the attack failed to escape manipulation, with current President Trump typically seizing the moment to criticize his predecessor's failure to prevent the attack or, during the last presidential campaign, to show footage of his rival, Hilary Clinton, stumbling while leaving the service as "proof" of her unsuitability for office. While Shakespeare and Cervantes can hardly be accused of serving such opportunist

7 Trapiello's own contribution to making Cervantes more accessible was a modernlanguage edition of Don Quixote (2015) which is now freely available online for use in schools and colleges (http://www.iesmontevives.es/sites/default/files/archivos adjuntos/Quijote\%20de\%20Trapiello.pdf). Prefaced by no less an authority than Mario Vargas Llosa, this simplified version, together with Pérez-Reverte's earlier abridged and "digression-free" rewriting (2014), has perhaps predictably rankled certain sectors of Spanish academia who have gone so far as to dub it an "embarrassment" and a "crime against literature" (Arranz). 
ends, the "industry" which has grown around the former especially, or his invocation in the least ennobling of conflicts, raise serious questions about the neutrality of idolatry.

But what $9 / 11$ also throws into relief is a less explicit aspect of commemoration that inevitably fed into the quatercentenary: the existence of crisis. "We are living in a world witnessing multiple and intersecting crises," warns a recent study of memory and recovery (Larkan \& Murphy 1). The UK referendum on leaving Europe, the rise of right-wing extremism across Europe and the US, the ongoing refugee crisis, years of hardship under austerity and public debates about man-made climate change are all cited as the "crisisscapes" which have brought notions of memory, forgetting, recovery and crisis to the forefront of social scientific analysis. The claim of national purity is arguably all the more urgent and necessary at a time when both Britishness and Spanishness are (so to speak) up for grabs, requiring substantial redefinition before, on the one hand, withdrawal from the European Union and, on the other, the possible segregation of one of the nation's most important and prosperous regions. Neither Brexit nor the crisis in Catalonia were adduced as explicit motivations for the impending ceremonies, but the strong state presence in both initiatives and the heavy regional participation in the second, which included a representative of the Catalan government, point to clear links between the figure of the person or event commemorated and a loosely defined concept of national identity. Though obviously not determining the celebration of the Shakespeare and Cervantes centenaries, Brexit and the situation in Catalonia have both impinged on the manner in which both events have been articulated. Commemoration, that is, could also have a kind of mythopoeic function, keeping alive the illusion of a togetherness and sustaining even larger narratives that, as Graham Holderness (xiii) put it in a different context, speak of "unity, integration and harmony in the cultural superstructures of a divided and fractured society".

If Shakespeare's status as the "national" British poet was, as Michael Dobson and others have influentially argued, established at least as early as the Restoration, it is striking to see how similar assertions of Shakespeare's nationality and nationhood resurface at the very point the concept of Britishness is at stake. Coming on the back of the September 2014 referendum on Scottish independence, which was narrowly averted, and just a few months before arguably the most important vote in recent British history, on whether the UK should leave the European Union, the quatercentenary celebrations were pitched not just as a tribute to Shakespeare but, as the then Foreign and Commonwealth Office minister Hugo Swire put it, "the most significant soft power opportunity for the UK in recent times" (Daily Hansard). Perhaps fittingly, it was the man responsible for calling both referenda, Prime Minister David Cameron, who led 
the celebrations with a confirmation of Shakespeare's centrality to British identity as well as of his impact on the international community. Shakespeare's Britishness is at the heart of Cameron's carefully worded inauguration of "Shakespeare Lives". Shakespeare, he claimed, "lives today in our language, our culture and society", an appeal to "us-ness" which, through the writer's "enduring influence on education" and the outreach work of British institutions like the RSC and Shakespeare's Globe, would spread its tentacles across the world, as far as China and Zimbabwe, or, as in the Globe world tour, "from Iraq to Denmark". The sheer range of the countries mentioned-a communist mega-state, a socialist former British colony where Shakespeare has escaped censorship even in his most anti-tyrannical mode, a member of the evil axis once demonized by Bush and a member of the EU which, like Britain, has steadfastly retained its own currency-is, it was assumed, incontrovertible proof of Shakespeare's ability to overcome local differences and, by inference, of Britain's continued influence over the world at large.

By comparison, the Spanish celebrations were more domesticallyoriented, insisting on those aspects of Cervantes which bolstered the idea of a "national" identity, composed of, but at the same time overarching, the different regionalisms into which the "nation" is actually divided. Again the context here is all-important: the celebrations were being planned just months after a consultation of the Catalan people had revealed that some eighty percent were in favour of independence from Spain. The unifying impulse for the quatercentenary was evident in the very composition of the committee charged with overseeing the commemorative acts which constituted the quatercentenary. Indeed, as the "royal decree" passed in parliament on 17 April 2015 makes clear (Real Decreto), the Spanish celebrations were officially orchestrated by a committee comprising a range of public organisms, including representatives from six of the Autonomous Communities with which the name of Cervantes is generally associated. As Honorary Presidents stood the King and Queen of Spain, while the rest of the committee, from the Vice-president of the People's Party government to a representative from the State Society for Cultural Action, was composed exclusively of members of public or semi-public institutions. Chief amongst them were the respective heads of the Instituto Cervantes and the Real Academia de la Lengua, who together performed a role similar to that of the British Council, channelling different cultural initiatives to reach audiences both at home and in a number of extra-territorial locations, chiefly Spanishspeaking South America.

The official post-commemorative accounts of the Cervantes fourth centenary suggest a very different narrative from that propagated on television and in the press, which took place before Rajoy's People's Party secured a mandate for its second, albeit minority, government on 27 June 2016. The 
discrepancy is not just in terms of the number of activities (exhibitions, performances, publications and projects) produced but in terms of the significance of the Cervantine legacy. To a question raised in the Spanish parliament on 8 March 2017 by a representative of the Quixote-region of Castilla-La Mancha, the Minister of Education, Culture and Sport, Íñigo Méndez de Vigo, gave the statistical lie to the doom-laden predictions made in the buildup to the event. So, together with the 301 officially approved "cultural activities", 123 publications and studies and 491 projects, there had, he claims, been literally "millions" of events which simply did not feature on the Ministry's specially created website. As to the delegate's familiar appeal to Cervantes' universality, the minister reminded his questioner of the participation of schools and "civil society", together with the transmission ("irradiación") of the writer's life and work to Latin America, before mentioning that the annual Premio Cervantes, Spain's most prestigious national literary award, would be given to "don" Eduardo Mendoza-a Catalan novelist who writes mainly in Spanish (Diario de Sesiones 29)!

Méndez de Vigo's triumphal intervention in parliament, coming just weeks before the Catalan leader Carles Puigedemont was to call for a second, and this time "binding", referendum in the region, was legitimized by a speech, made a few days earlier, by the King of Spain, Felipe VI ("Palabras de Su Majestad"). Like Cameron's introduction to the "Shakespeare's Lives" project, Felipe's address to the authorities that had made the Cervantes quatercentenary possible is a masterful piece of mythopoesis. The Shakespeare "lives" idea, which had caused so much mirth in the British House of Commons when it was first mooted, was adopted with characteristic solemnity by Felipe in his end-ofevent address to the organizers of the Cervantes event. Underpinning the royal concept of a Cervantine afterlife was the perdurance of his work, his influence and also the "values" associated with them: the "ideal of justice, of tolerance, of freedom, of beauty, of solidarity, of love or of friendship" that are the hallmark of "Cervantine society" and, through Cervantes, the bases of a nation's "collective identity". It is surely no coincidence that, with the Catalan crisis already looming, the values that the monarch put most emphasis on should be precisely those of "freedom and dialogue". Meanwhile the "plural and enriching identity" of the territory explored by Don Quixote and Sancho, explicitly identified as the lands of Castile, La Mancha, Andalusia, Aragon and last but not least Catalonia, should be cited as the object of an author who "marked a moral and vital path for us to follow, which does not end in a sterile fight against windmills but in the belief of the possibility of a shared history of fruitful coexistence, ceaselessly projected towards the future". The ongoing influence and popularity of Cervantes is, it is claimed, a consequence of the values, especially unity within plurality, his work is assumed to embody. 


\section{The Heritage Industry}

In both quatercentenaries the State-whether government itself or the cultural organisms dependent on it-played a prominent role, directly stimulating the celebrations or, as in the Spanish case, channelling and approving the activities to be funded or sponsored. This support is of course not disinterested: showcasing such cultural assets as Shakespeare or Cervantes is an important boost to a nation's "brand" and so its commercial standing in the international market; by the same token, it can, as we have seen, bring ideological dividends such as the illusion of power over other countries or, as in the Spanish case, the myth of national unity. The economic implications of this are not to be underestimated, especially bearing in mind that Spain had only recently begun to emerge from a severe crisis where, according to the most pessimistic reports (Shim), direct public investment in the arts fell as low as one percent. This is doubtlessly why written into the 2015 decree was a clause classing the event as "of exceptional public interest" and thereby promising fiscal incentives of up to ninety percent to non-profit-making bodies and private "sponsors" willing to take part. As part of an additional cost-saving package of measures, the decree specifies that membership of the national committee would be purely honorary, that the dayto-day running of the committee would fall to civil servants already working for the Ministry of Culture and that the institutions represented on the committee together with any other public or private body involved in the celebrations were free "to make contributions or collect moneys to fund the [commemorative] activities" (Real Decreto).

Much of the criticism levelled at the Spanish government over the running of the Cervantes event sprang, as we saw, precisely from the perception that it was not putting as much financial muscle into it as its British counterpart. Now, this is not strictly fair since, as Jennifer Craik (51) has shown, for years governments across the globe have tended to adopt a "mix-and-match" approach to arts funding, combining traditional direct patronage strategies, indirect funding through "arms' length" agencies such as art councils, ministerial directorates and departmental arrangements, and finally what she calls "facilitative strategies" designed "to build philanthropic, sponsorship and partnership liaisons between culture and public and private sector agencies, clients and communities". Part of the problem in the Spanish case is, since the inevitable fall-off in the direct patronage approach, rather too much onus was placed on agencies like the already under-funded Instituto Cervantes or on the basic good will of private sponsorship agencies such as banks, which themselves had undergone major restructuring as a result of an EU bail-out to the tune of over seventy billion euros. The private-funding model may well be working at institutions like the Museo del Prado in Madrid, which now relies sixty percent on private donations, but the lack of private sponsorship culture in Spain meant 
that it had little impact on the quatercentenary where only forty corporations responded to the government offer and then only after certain local politicians, amongst them the mayor of Cervantes' home town Alcalá de Henares, had practically had to go begging for the cash (Gibson 146).

In a blog entitled "Cervantes, Shakespeare y Rajoy", dated 12 March 2016, Pérez-Reverte would ask how after four hundred years no-one had had the time to prepare a decent quatercentenary for Cervantes, as they had for Shakespeare in Britain. He did nonetheless take ironic solace in the fact that:

The best monument to Cervantes and to his Quixote, what gives meaning to that extraordinary book, is precisely the country that made it possible: that forgetful, ungrateful, disloyal, miserable, unsupportive, suicidally illiterate place, without which the book that best defines us could never have been written. (PérezReverte)

The great unwritten of what Pérez-Reverte calls the "international embarrassment of the Cervantes year" was political and economic instability and also a fracturing of the nation's "identity" which no amount of commemorative fervour could properly conceal. That similar issues may well have underwritten the British event, however potently it was marketed and internationally celebrated, is, I would contend, a story still waiting to be told.

\section{WORKS CITED}

“Aquí yacen los huesos de Cervantes, o esoYparece.” National Geographic 3 November 2016. 25 April 2019. <http://www.nationalgeographic.com.es/historia/aquiyacen-los-huesos-de-cervantes-o-eso-parece_9091>.

Arranz, David Felipe. "En defense de El Quijote de Cervantes.” El imparcial 23 August 2015. 1 October 2017. <https://www.elimparcial.es/noticia/154958/opinion/Endefensa-de-El-Quijote-de-Cervantes.html $>$.

Astrana Marín, Luis. "Estudio preliminar." William Shakespeare. Obras completas. Madrid: Espasa Calpe, 1941. xi-cxliv.

Bloom, Harold. The Western Canon: The Books and School of the Ages. New York: Harcourt Brace, 1994.

Calvo, Clara. "Shakespeare and Cervantes in 1916: The Politics of Language." Shifting the Scene: Shakespeare in European Culture. Eds Balz Engler and L. Bezzola. Newark: U. Delaware P., 2004. 78-94.

Cameron, David. "Opening address." Shakespeare Lives. <https://www.gov.uk/ government/news/shakespeare-lives-on>.

Craik, Jennifer. Re-Visioning Arts and Cultural Policy: Current Impasses and Future Directions. Canberra: Australia National University E Press, 2007. 1 October 2017. <http://www.culturaldiplomacy.org/academy/pdf/research/books/cultural_ diplomacy/Re-Visioning_Arts_and_Cultural_Policy___Jennifer_Craik.pdf $>$. 
Daily Hansard 10 November 2015: Column 1WH._<https://publications.parliament.uk/ $\mathrm{pa} / \mathrm{cm} 201516 / \mathrm{cmhansrd} / \mathrm{cm} 151110 / \mathrm{halltext} / 151110 \mathrm{~h} 0001 . \mathrm{htm}>$.

Diario de Sesiones del Congreso de los Diputados (35) 8 March 2017: 1-47. <http:// www.congreso.es/public_oficiales/L12/CONG/DS/PL/DSCD-12-PL-35.PDF>.

Dobson, Michael. The Making of the National Poet: Shakespeare, Adaptation, and Authorship, 1660-1769. Oxford: Clarendon, 1992.

Erll, Astrid and Ann Rigney. "Introduction: Cultural Memory and Its Dynamics." Mediation, Remediation, and Cultural Memory. Eds. Astrid Erll and Ann Rigney. Berlin and New York: De Gruyter, 2009. 1-14.

Frijda, Nico H. The Laws of Emotion. New York: Routledge, 2007.

Gibson, Ian. Aventuras ibéricas. Recorridos, reflexiones e irreverencias. Barcelona: Ediciones B, 2017.

González Fernández de Sevilla, José Manuel. Introduction. Shakespeare and Cervantes. New Interpretations and Comparative Approaches. Ed. José Manuel González Fernández de Sevilla. Alicante: Universidad de Alicante, 2016. 1-11.

González Ruiz, Nicolás. Dos genios contemporáneos: Cervantes y Shakespeare. Barcelona: Clarasó, 1944.

Gregor, Keith. "Collaborative Encounters? Two Recent Spanish Takes on the Shakespeare-Cervantes Relationship." Palgrave Communications 2. 14 June 2016. <https://papers.ssrn.com/sol3/papers.cfm?abstract_id=2828633>.

- - - Shakespeare in the Spanish Theatre, 1772 to the Present. New York and London: Continuum, 2010.

Hoenselaars, Ton and Clara Calvo. "Introduction: Shakespeare and the Cultures of Commemoration." Critical Survey 22.2 (2010): 1-10.

Holderness, Graham. "Preface: 'All This'." The Shakespeare Myth. Ed. Graham Holderness. Manchester: Manchester U.P., 1988. xi-xvi.

Kahn, Coppélia. "Remembering Shakespeare Imperially: The 1916 Tercentenary," Shakespeare Quarterly 52.4 (2001): 456-478.

Larkan, Fiona and Fiona Murphy. "Introduction." Memory and Recovery in Times of Crisis. Eds. Fiona Larkan and Fiona Murphy. London and New York: Routledge, 2017. 1-8.

Monterrey, Tomás. "Notes for a History of English Studies in Spain." European English Studies: Contributions towards the History of a Discipline. Eds. Balz Engler and Renate Haas. Leicester: The English Association for ESSE, 2000. 33-52.

"Palabras de Su Majestad el Rey en el acto de clausura de la conmemoración del IV centenario de la muerte de Miguel de Cervantes." Casa de Su Majestad el Rey. Actividades y Agenda. 30 January 2017. <http://www.casareal.es/ES/ Actividades/Paginas/actividades_discursos_detalle.aspx?data $=5640>$.

"Parliamentary Debates," Hansard (604.93) 7 January 2016. <https://hansard. digiminster.com/pdf/Commons/2016-01-07>.

Pérez-Reverte, Arturo. “Cervantes, Shakespeare y Rajoy.” XL Seminal 12 March 2016. 1 October 2017. <http://www.perezreverte.com/articulo/patentes-corso/1080/ cervantes-shakespeare-y-rajoy>.

Pujante, Ángel Luis and Laura Campillo, eds. Shakespeare en España. Textos 17641916. Granada and Murcia: Universidad de Granada and Universidad de Murcia, 2007. 
Pujante, Ángel Luis. "Shakespeare or/and...? The Spanish Counterpart in the $18^{\text {th }}$ and $19^{\text {th }}$ Centuries." Renaissance Refractions. Essays in Honour of Alexander Shurbanov. Eds. Boika Sokolova and E. Pancheva. Sofia: St. Kliment Ohridski University, 2001. 157-169.

Pujols, Carlos. “El Shakespeare de los sonetos,” Destino 1421 (1964): 38-39.

Real Decreto 289/2015, de 17 de abril, por el que se crea y se regula la Comisión Nacional para la conmemoración del IV Centenario de la muerte de Miguel de Cervantes. Boletín Oficial del Estado 23 April 2015. <https:/www.boe.es/ buscar/doc.php?id=BOE-A-2015-4393 $\geq$.

Ruiz Mantilla, Jesús. “Que los ingleses se queden a Cervantes; lo tratarán mejor.” El país 28 January 2016. 1 October 2017.

Sainz Borgo, Karina. "El año Shakespeare tendrá actividades en 140 países, España dedica a Cervantes menos de la mitad.” Vozpópuli 28 January 2016. 1 October 2017. <http://www.vozpopuli.com/altavoz/cultura/William_Shakespeare-Miguel_ de_Cervantes-Centenarios-IV_Centenario_Cervantes-IV_Centenario_ShakespeareLiteratura-Shakespeare_0_884311622.html>.

Service, William Robert. Rhymes of a Roughneck. More Collected Verse. New York: Dodd, 1953.

Shim, Eileen. "The Private Sector Bail-Out of Europe's Culture Industry." New Republic 16 November 2012. 1 October 2017. <https://newrepublic.com/article/110224/ private-sector-bail-out-europes-culture-industry $>$.

Simpson, David. "Introduction: Taking Time." 9/11. The Culture of Commemoration. Chicago and London: U. Chicago P., 2006. 1-20.

Somoza, José. "Una conversación del otro mundo, entre el español Cervantes y el inglés Shakespeare," Seminario Pintoresco 2 (1838): 691-692.

Watson, Nicola J. The Literary Tourist: Readers and Places in Romantic and Victorian Britain. Basingstoke and New York: Palgrave Macmillan, 2006.

Weikart, Lynne A. Follow the Money: Who Controls New York City Mayors? Albany: State U. of New York P., 2009. 